\title{
Effects of carbachol on apoptosis in human chronic myelogenous leukemic K562 cell line
}

\author{
İnsan kronik miyeloid lösemi K562 hücrelerinde karbakolün apoptoza etkisi
}

\author{
Banu AYDIN, Aysın TULUNAY, Emel EKŞİOĞLU-DEMIRALP, Beki KAN, Hulya CABADAK
}

\begin{abstract}
Objectives: Muscarinic receptors mediate diverse actions of acetylcholine in the central nervous system and in non-nervous tissues innervated by the parasympathetic nervous system. Our study aims to evaluate the potential association of the $\mathrm{M}_{3}$ muscarinic receptor with K562 cell proliferation and death.

Materials and Methods: Cell proliferation was evaluated by bromodeoxyuridine (BrDU) incorporation. To show early, late apoptosis and cell death, cells were labelled with Annexin $\mathrm{V}$, propidium iodide (PI) and analyzed by flow cytometry. Nuclear extracellular signal-regulated kinase (ERK/pERK) expression was measured by western blot analysis.

Results: Treatment with carbachol (CCh) for $48 \mathrm{~h}$ decreased cell number. Exposing K562 cells to $\mathrm{CCh}$ for $24 \mathrm{~h}$ decreased the number of early apoptotic cells but did not change the number of late apoptotic and necrotic cells. CCh treatment for $48 \mathrm{~h}$ increased the number of necrotic cells, but decreased the number of early and late apoptotic cells. In response to CCh, nuclear ERK expression was increased and this effect was reversed by 1,1-dimethyl-4-diphenylacetoxypiperidinium iodide (4DAMP). Nuclear pERK expression was decreased in CCh treated cells, 4DAMP did not reverse the effect.

Conclusion: Our data suggest that cholinergic agonist $\mathrm{CCh}$ affects cell proliferation in K562 cells not only through muscarinic receptors but also through other cholinergic receptors.
\end{abstract}

Keywords: Muscarinic receptors, K562 cells, Carbachol, Cholinergic system

Banu Aydın(凶), Hulya Cabadak

Department of Biophysics, School of Medicine, Marmara University, Maltepe, Istanbul, Turkey

e-mail: banu.aydin@gmail.com

Aysin Tulunay

Institute of Infection, Immunity and Inflammation, University of Glasgow, Glasgow, United Kingdom

Emel Eksioglu-Demiralp

Tissue Typing and Immunology Laboratory, Memorial Sisli Hospital, Sisli, Istanbul, Turkey

Beki Kan

Department of Biophysics, School of Medicine, Acibadem Mehmet Ali Aydinlar University, Kayisdagi, Istanbul, Turkey

Submitted / Gönderilme: 02.10.2018

Accepted/Kabul: 13.12.2018
ÖZ

Amaç: Muskarinik reseptörler merkezi sinir sisteminde asetilkolinin çeşitli etkilerine aracılık ettiği gibi, parasempatik sinir sistemi ile etkileşen sinirsel olmayan dokulara da aracılık ederler. Çalışmamızda, $M_{3}$ muskarinik reseptör alttipinin K562 kanser hücre çoğalması ve ölümündeki rolünü belirlemeye çalıştık.

Gereçler ve Yöntemler: Hücre çoğalması bromodeoksiüridin (BrDU) yöntemi ile belirlenmiştir. Hücre ölümü, erken ve geç apoptoz Anneksin V ve propidyum iodid (PI) varlığında akış sitometrisi yöntemi ile gösterilmiştir. Nuklear dış sinyal düzenleyici kinaz (ERK/fosfo-ERK) ekspresyonu western emdirimi yöntemi ile belirlenmiştir.

Bulgular: Çalışmamızda 48 saat karbakol(CCh) ile muamele edilen K562 hücre sayısında azalma belirlenmiştir. Hücreler 24 saat CCh ile muamele edildiklerinde erken apoptotik hücre sayısında azalma gözlemlenirken geç apoptoz ve nekrotik hücre sayısında değişim olmamıştır. Bununla birlikte, 48 saat boyunca CCh ile muamele olan hücrelerde, erken ve geç apoptotik hücre sayısı azalırken, nekrotik hücrelerin sayısı artmıştır. CCh ile muamele edilen hücrelerde nüklear ERK ekspresyonu artarken bu etki 1,1-dimetil-4-difenilasetoksipiperidinium iodid (4DAMP) ile geri çevrilmiştir. Aynı koşullarda CCh ile muamele edilen hücrelerde nuklear pERK ekspresyonu azalmış, bu etki 4DAMP ile geri çevrilmemiştir.

Sonuç: Bulgularımız, K562 hücre proliferasyonundaki kolinerjik etkinin yalnızca muskarinik mekanizma ile değil diğer kolinerjik reseptörlerin de katkısıyla gerçekleştiğini düşündürmektedir.

Anahtar kelimeler: Muskarinik reseptör, K562 hücreleri, Karbakol, Kolinerjik sistem

\section{Introduction}

G-protein-coupled receptors (GPCRs), the largest family of cell-surface molecules involved in signal transmission, have recently emerged as crucial players in tumour growth and metastasis. These receptors control key physiological functions, including neurotransmission, hormone and enzyme release from endocrine and exocrine 
glands, immune responses, cardiac - and smooth-muscle contraction and blood pressure regulation, just to name a few. Their dysfunction contributes to some human diseases; therefore, GPCRs represent the target of $50-60 \%$ of all current therapeutic agents, either directly or indirectly [1].

Five subtypes $\left(\mathrm{M}_{1}-\mathrm{M}_{5}\right)$ of receptors with seven transmembrane segments are integral membrane proteins, bind with acetylcholine (ACh) in the extracellular segment, and thereafter interact with and activate GTP-binding regulatory proteins (G proteins) in the intracellular segment [2]. Three muscarinic receptor subtypes $\left(M_{1} R, M_{3} R\right.$, and $M_{5} R$ ) stimulating cellular signaling are conditional oncogenes when expressed in cells capable of proliferation [3]. Many studies have shown that cholinergic agonist carbachol $(\mathrm{CCh})$ induced cancer cell proliferation $[4,5]$.

Leukemia is a clonal disorder characterized by blocked normal differentiation and cell death of hematopoietic progenitor cells. Chronic myelogenous leukemia (CML), is a hematopoietic stem cell disorder with increased production of granulocytes at all stages of differentiation, leading to a myeloproliferative syndrome [6,7]. The K562 cell line derived from a CML patient during blast crisis was examined for properties of $\mathrm{B}$ and $\mathrm{T}$ lymphocytes and cell lines. Although K562 cells have some T cell properties, these are not exclusive [8]. K562 cell lines are good models for studying cell proliferation and apoptosis in CML. We have previously demonstrated that $\mathrm{CCh}$ decreased proliferation of K562 cells supplemented after starvation with 1\% serum in $24 \mathrm{~h}$, an effect prevented by atropine [9].

Apoptosis is one of the ways for cell death that is referred to as programmed cell death (PCD). It plays important roles in embryonic development, immune system maturation and cytotoxic effector function, and carcinogenesis [10]. Apoptosis is executed by two pathways. Death receptors, such as Fas and tumor necrosis factor-related apoptosisinducing ligand (TRAIL) DR4 and DR5 trigger the extrinsic/ death receptor pathway [11]. The response to radiation or cytotoxic drug-induced cellular stress activates the intrinsic/ mitochondria-dependent pathway [12]. The development of new therapies for the treatment of cancer has been possible by studying apoptotic processes [13].

Programmed cell death uses adenosine triphosphate (ATP), synthesizes new RNA and protein and thus forms active cellular suicide. PCD activates endogenous endonucleases that degrade the cell's DNA. Thereafter, the genetic template required for cellular homeostasis is destroyed [14]. However, there are various ways for cell death, for example hypoxia and exposure to certain toxins cause the form of cell death termed "necrosis".
Increased membrane permeability, cell swelling, and rupture are the early events; whereas, loss of plasma membrane integrity is a relatively late event in PCD. PCD seems to play an important role in several physiological situations [15].

In neurons, it has been shown that muscarinic receptors act via activation of the extracellular signal-regulated kinases 1 and $2($ ERK1/2) which are referred to as mitogen-activated protein (MAP) kinase 1 [16]. $\mathrm{M}_{3} \mathrm{R}$ has an important role in the endogenous and exogenous ACh-induced cell proliferation and phosphorylation of ERK and AKT in gastric cancer cells [17].

\section{Materials and Methods}

Carbachol, 4DAMP, atropine, Roswell Park Memorial Institute 1640 (RPMI-1640) medium were purchased from Sigma Chemical Co, St. Louis, MO, USA. Fetal bovine serum (FBS) was obtained from Biol. Ind. (Beit Haemek, Israel). Nitro Blue Tetrazolium/5-Bromo-4-Chloro-3-indolyl - phosphate (NBT/BCIP) were purchased from Promega (Madison, WI, USA). phosphorylated ERK (pERK), $\beta$-actin antibodies were supplied by Santa Cruz Biotechnology, Inc. (Santa Cruz, CA, USA). Secondary antibodies were purchased from Sigma ( $\mathrm{St}$ Louis, MO, USA).

\section{Cell culture}

K562 cells were grown in suspension using RPMI medium supplemented with $10 \%$ fetal calf serum at $37^{\circ} \mathrm{C}$ in a $5 \%$ $\mathrm{CO} 2$ humidified atmosphere. Cells were usually seeded at a density of $10^{5}$ cells $/ \mathrm{ml}$ and one half of the medium was replaced every 3-4 days. These cells were then starved by seeding into flasks containing RPMI-1640 medium with $0 \%$ FBS. Afterwards, these "starved cells" were placed into a medium containing $1 \%$ serum, with and without $100 \mu \mathrm{M}$ CCh, $10 \mu \mathrm{M}$ 1,1-dimethyl-4-diphenylacetoxypiperidinium iodide (4DAMP), $10 \mu \mathrm{M}$ atropine for different times.

\section{Cell counting}

The change in K562 cell count in response to CCh stimulation was evaluated by assessing proliferation and cell viability by the trypan blue exclusion test and bromodeoxyuridine (BrDU) labeling, respectively. The contribution of muscarinic receptors was investigated by using the non-specific muscarinic antagonist, atropine. Cell counting was carried out using an ELISA reader (Multiskan Microplate Reader, Thermo Scientific, USA). K562 cells were treated with 0-100 $\mu \mathrm{M} \mathrm{CCh}$ and/or antagonist atropine $(10 \mu \mathrm{M})$ for $48 \mathrm{~h}$ and aliquots were 
removed at indicated times. Antagonist was added $30 \mathrm{~min}$ prior to $\mathrm{CCh}$. The average of 3 experiments performed in duplicate was used for data analysis.

\section{Flow cytometric analysis}

In order to detect early and late apoptosis and cell death, cells were stained with FITC conjugated Annexin V and propidium iodide (PI) according to the manufacturer's instructions. Samples were then analyzed by flow cytometry (BD FACS Canto, Becton, Dickinson and Company, USA).

\section{Western blot analysis}

K562 cells were treated with $100 \mu \mathrm{M}$ CCh and/or $\mathrm{M}_{3} \mathrm{R}$ selective antagonist 4DAMP $(10 \mu \mathrm{M})$ for 5 minutes. The duration of $\mathrm{CCh}$ treatment was determined by our previous studies (unpublished data). Antagonist, 4DAMP $(10 \mu \mathrm{m})$ was added $30 \mathrm{~min}$ prior to $\mathrm{CCh}$. After addition of CCh and 4DAMP, cells were washed with phosphate-buffered saline (PBS) and were later frozen at $-80{ }^{\circ} \mathrm{C}$ until further treatment. The frozen cells were homogenized in ice-cold $10 \mathrm{mM}$ Tris- $\mathrm{HCl}$ (pH 7.2) buffer containing $1 \mathrm{mM}$ EDTA and protease inhibitors $(0.2$ mM PMSF, $1 \mathrm{~g} / \mathrm{ml}$ leupeptin, $1 \mathrm{M}$ pepsitatine, $10 \mathrm{~g} / \mathrm{ml}$ soybean trypsin inhibitors) with a 9-gauge needle. The samples were centrifuged at $300 \times \mathrm{g}$ for $5 \mathrm{~min}$ at $4{ }^{\circ} \mathrm{C}$. The resulting supernatant was centrifuged at $13000 \mathrm{xg}$ for $20 \mathrm{~min}$ at $4^{\circ} \mathrm{C}$. The pellets were resuspended and washed twice in the same buffer and stored at $-80{ }^{\circ} \mathrm{C}$. The protein content of pellets was determined by the Lowry method [18]. $50 \mu \mathrm{g}$ of protein was loaded onto sodium dodecyl sulfate-polyacrylamide gels and electrophoretically transferred onto nitrocellulose membranes (Schleicher and Schuell, $0.45 \mathrm{~m}$, Germany). The membranes were blocked at room temperature for $60 \mathrm{~min}$. Later the membranes were incubated overnight at $4{ }^{\circ} \mathrm{C}$ with antibodies against ERK and pERK (1/500). The blots were washed with TBS containing $0.05 \%$ Tween-20 (TBS-T) and were later incubated with alkaline phosphatase-conjugated secondary antibodies for $1 \mathrm{~h}$ at room temperature $\left(20{ }^{\circ} \mathrm{C}\right)$. The antibody-antigen complex was detected with nitra blue tetrazolium (NBT)/5-bromo4-chloro-3-indolyl phosphate (BCIP). The densitometric analyses were carried out with Bio-Rad Molecular Analyst software (free edition, www.totallab.com).

\section{Results}

\section{Effect of CCh on $\mathrm{K562}$ cells proliferation}

In this study, we showed that there was a decrease in cell number in the group treated with $100 \mu \mathrm{M} \mathrm{CCh}$ for $48 \mathrm{~h}$ when compared to the control group. However, this decrease was not reversed by atropine treatment (Figure 1).

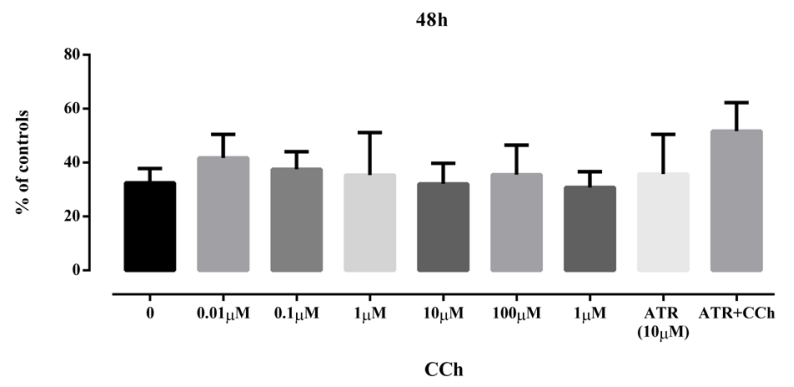

Figure 1. Effect of $\mathrm{CCh}$ on K562 cells proliferation. K562 cells were treated with $0-100 \mu \mathrm{M} \mathrm{CCh}, 10 \mu \mathrm{M}$ atropine, $100 \mu \mathrm{M} \mathrm{CCh}$ and $10 \mu \mathrm{M}$ atropine for 48 hours. Control cells were not treated with $\mathrm{CCh}$. The results were shown as \pm SEM by taking the average of 3 experiments. ATR: Atropine.

\section{Effect of CCh on $\mathrm{K562}$ cells apoptosis}

We demonstrated that after exposing K562 cells to 100 $\mu \mathrm{M} \mathrm{CCh}$ for $24 \mathrm{~h}$ the number of early apoptotic cells was decreased by $\sim 10 \%$ but no change was observed in the number of late apoptotic and necrotic cells. After treatment with CCh for 48h, the number of necrotic cells was increased by 1.5 -fold whereas apoptotic cells were decreased by 1.55-fold compared to control cells (Figure 2).
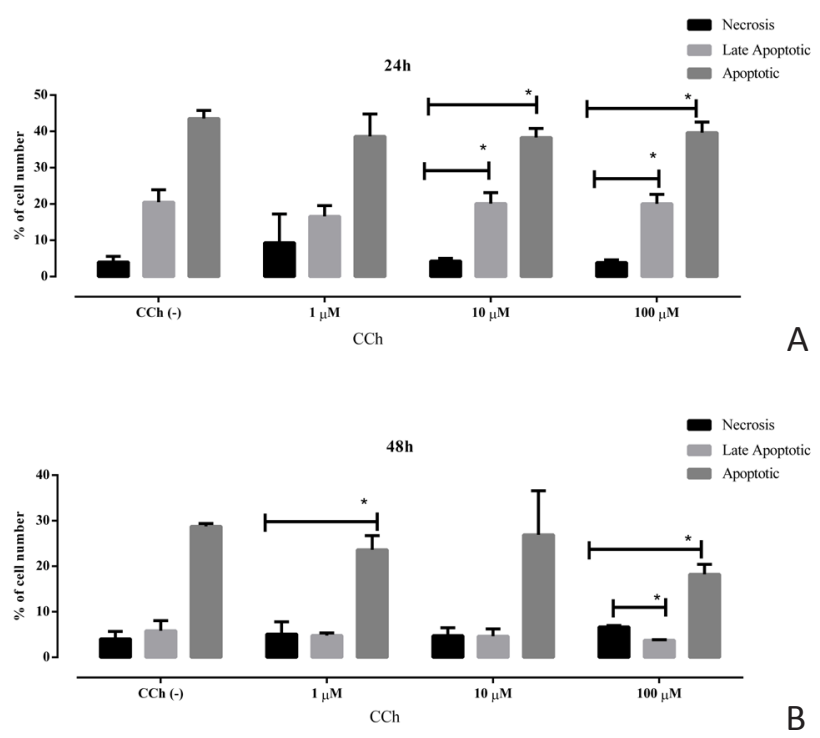

Figure 2. Effect of CCh on K562 cells apoptosis. K562 cells were treated with $0-100 \mu \mathrm{M} \mathrm{CCh}$ for (A) $24 \mathrm{~h}$ and (B) $48 \mathrm{~h}$. Control cells were not treated with $\mathrm{CCh}$. The results were shown as \pm SEM by taking the average of 3 experiments. ${ }^{*} \mathrm{P}<0.05$ for significant change compared with the $\mathrm{CCh}$ (-) group. 


\section{Effect of CCh on nuclear ERK expression}

In cells treated with $\mathrm{CCh}$ for 5 min, nuclear ERK expression was increased by $14 \%$ compared to the control, but this increase was found to be $3 \%$ in cells treated with 4DAMP prior to $\mathrm{CCh}$ (Figure 3). On the other hand, in cells treated with $\mathrm{CCh}$ for $5 \mathrm{~min}$, expression of nuclear pERK was reduced by $22 \%$ compared to the control, however this effect was not antagonized by 4DAMP (Figure 4).
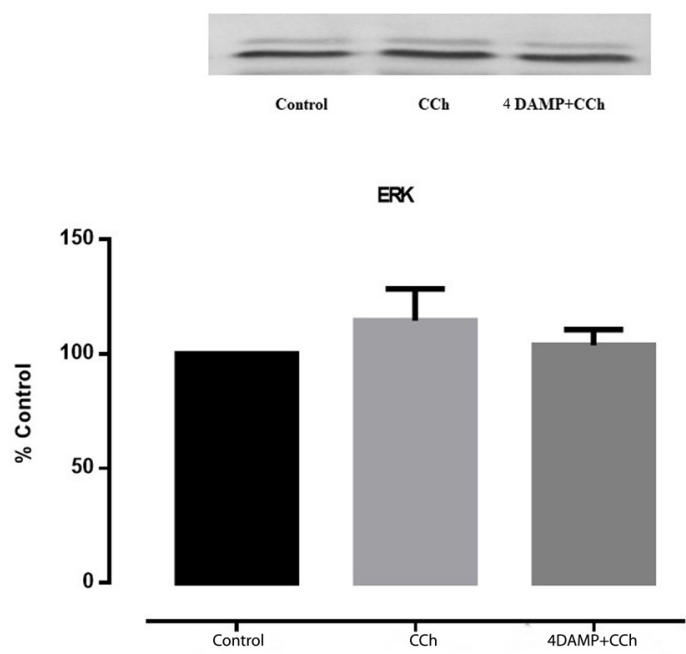

Figure 3. Effect of $\mathrm{CCh}$ on nuclear ERK expression. K562 cells were treated with $100 \mu \mathrm{M}$ CCh for $5 \mathrm{~min}$. Antagonist, 4DAMP $(10 \mu \mathrm{m})$ was added 30 min prior to $\mathrm{CCh}$. Control cells were not treated with $\mathrm{CCh}$. Percent increase in ERK expression relative to control in cells. The results were shown as \pm standard error (SD) by taking the average of 3 experiments.
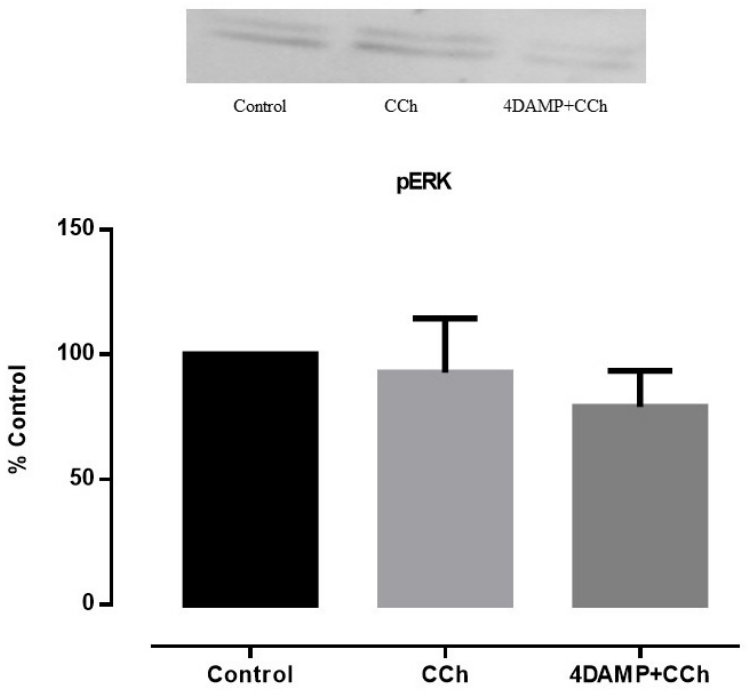

Figure 4. Effect of CCh on nuclear pERK expression. K562 cells were treated with $100 \mu \mathrm{M}$ CCh for $5 \mathrm{~min}$. Antagonist, 4DAMP $(10 \mu \mathrm{m})$ was added $30 \mathrm{~min}$ prior to $\mathrm{CCh}$. Control cells were not treated with CCh. Percent increase in pERK expression relative to control in cells. The results were shown as \pm standard error (SD) by taking the average of 3 experiments.

\section{Statistical analysis}

All data were expressed as mean \pm SEM. Multiple $t$ tests were used for the analysis of data. For all statistical calculations, significance was considered to be a value of $\mathrm{P}<0.05$.

\section{Discussion}

Acetylcholine serves as a neurotransmitter both in the central and the peripheral nervous systems, where it controls functions including muscle contraction, neurotransmission among others. Recent studies demonstrating that ACh also regulates cell proliferation [19] and apoptosis [20] initiated research on the role of $\mathrm{nAChRs}$ and $\mathrm{mAChRs}$ in the development and progression of cancer and in stem cell physiology. Based on these studies, we asked whether the $\mathrm{M}_{3} \mathrm{R}$ subtype may affect the proliferation of the K562 cell line.

Muscarinic receptor agonists stimulate cell proliferation, survival, migration, and invasion, as shown by in vitro studies using human colon cancer cells. These effects are regulated by complex mechanisms involving interacting post-M $\mathrm{R}$ signaling pathways which activate post-receptor signaling cascades [21]. Colon cancer cell proliferation is regulated by rapid, reversible activation of ERK1/2; whereas, cell survival and resistance to radiation is regulated by PI3K/AKT activation $[21,22]$. $\mathrm{M}_{3} \mathrm{R}$ activation stimulates colon cancer growth in animal models relevant to human colon cancer [23]. Similarly, $\mathrm{M}_{3} \mathrm{R}$ deficiency attenuates tumor formation [24,25]. Thus, $M_{3} R$ expression and activation seem to play important roles in in the progression of colon neoplasia. [26].

Expression of mRNAs of muscarinic receptors $\left(\mathrm{M}_{2}\right.$, $\mathrm{M}_{3}$ and $\mathrm{M}_{4}$ ) has been shown in K562 cells by using reverse transcription polymerase chain reaction and immunoblotting, but the roles of muscarinic receptors have not been clarified yet [27,28]. There is previous evidence suggesting that muscarinic receptors can regulate cell proliferation depending on the growth context of the cell. Whether cells are in a quiescent state or growing appear to determine the type of effect. Our previous data showed that in vitro proliferation of K562 cells was thoroughly dependent on the presence of fetal bovine serum that contained various growth factors. Treating serum-deprived K562 cells with a cholinergic agonist, CCh, a choline ester, led to a significant increase in DNA synthesis, implying the roles of cholinergic receptors in cell growth [9]. On the other hand, CCh produced a decrease in DNA synthesis in 
K562 cells supplemented with 1\% fetal bovine serum after starvation. We also demonstrated that phospholipase $\mathrm{C}$ and intracellular calcium were involved in CCh-mediated inhibition of proliferation in K562 cells [29]. These findings lend support to the hypothesis that $\mathrm{ACh}$ or $\mathrm{CCh}$ can generate intracellular effects through their action on cholinergic receptors. Our previous study demonstrated that $\mathrm{CCh}$ also enhanced NO production in K562 cells [9, 28]. The current study showed that treatment with $\mathrm{CCh}$ for $48 \mathrm{~h}$ decreased the cell number, indicating that $\mathrm{CCh}$ had a very fast and irreversible effect to promote cells to necrotic cell death. Supporting this hypothesis, decrease of cell number was not reversed by atropine treatment. Exposing K562 cells to 100 $\mu \mathrm{M}$ CCh for 24 hours decreased the number of apoptotic cells, possibly because of its promoting effect on necrosis. Treatment with $100 \mu \mathrm{M}$ CCh for 48 hours increased the number of necrotic cells whereas apoptotic cells were decreased compared to control cells (Figure 2). The increase in the necrotic cell number in 48 hours appeared to be compatible with decrease in cell proliferation.

Kodaira and his colleagues show that in gastric cancer, ERK signaling is observed following muscarinic receptor activation. However, the failure of ERK signaling to stimulate gastric cancer cell proliferation raises questions regarding the importance of this observation [30]. Expression of muscarinic receptors, ChAT (choline acetyltransferase), and CrAT (carnitine acetyltransferase), and ACh production, have been reported in human leukemia cell lines [31,32]. Shah and his colleagues show that muscarinic receptors and ligands play a major role in cancer, and then suggest that these possible carcinogens are an additional matter to investigate and environmental effects need to be addressed [33]. CCh affects cell proliferation via cholinergic receptors through ERK signaling [34]. In our experiments we demonstrated that ERK expression increased overall in response to $\mathrm{CCh}$ treatment, however, phospho-ERK expression was reduced when compared to control (Figure 4). Therefore, we suggest that increase in ERK indicates a cellular survival reflex of K562 cells, whereas CCh reduces the phosphorylation of ERK, which would otherwise promote proliferation.

In conclusion, our results support the notion that the cholinergic agonist $\mathrm{CCh}$ may have roles in cell death and affect cell proliferation by activating not only muscarinic receptors but also other signaling pathways. Future studies addressing a possible role for nicotinic acetylcholine receptors merit investigation.

\section{Funding}

This research was supported by grants supplied from TUBITAK (111S312) and Marmara University Research Fund (SAG-D-130.213.0058).

\section{Acknowledgments}

We would like to thank Prof. Tevfik Yoldemir, M.D. for English language editing

\section{References}

1. Pierce KL, Premont RT, Lefkowitz RJ. Seven transmembrane receptors. Nat Rev Mol Cell Biol 2002;3:639-50. doi: $10.1038 / \mathrm{nrm} 908$

2. Haga T. Molecular properties of muscarinic acetylcholine receptors. Proc Jpn Acad Ser B Phys Biol Sci 2013;89:22656. doi: $10.2183 /$ pjab. 89.226

3. Gutkind JS, Novotny EA, Brann MR, Robbins KC. Muscarinic acetylcholine receptor subtypes as agonist-dependent oncogenes. Proc Natl Acad Sci USA 1991;88:4703- 07.

4. Rayford W, Noble MJ, Austenfeld MA, Weigel J, Mebust WK, Shah GV. Muscarinic cholinergic receptors promote growth of human prostate cancer cells. Prostate 1997; 30:160-6. doi: 10.1002/(SICI)1097-0045(19970215)30:3<160::AID PROS3>3.0.CO;2-Q

5. Luthin GR, Wang P, Zhou H, Dhanasekaran D, Ruggieri MR. Role of $\mathrm{m} 1$ receptor-G protein coupling in cell proliferation in the prostate. Life Sci 1997;60:963-8. doi: 10.1016/S00243205(97)00035-0

6. Wang L, Jiang R, Song SD, Hua ZS, Wang JW, Wang YP. Angelica sinensis polysaccharide induces erythroid differentiation of human chronic myelogenous leukemia k562 cells. Asian Pac J Cancer Prev 2015;16:3715-21.

7. Taverna S, Giallombardo M, Pucci M, et al. Curcumin inhibits in vitro and in vivo chronic myelogenous leukemia cells growth: a possible role for exosomal disposal of miR-21. Oncotarget 2015;6:21918-33. doi: 10.18632/ oncotarget.4204

8. Klein E, Ben-Bassat H, Neumann H, et al. Properties of the K562 cell line, derived from a patient with chronic myeloid leukemia. Int J Can 1976;18:421-31. doi: 10.1002/ ijc.291.018.0405

9. Cabadak H, Aydin B, Kan B. Regulation of M2, M3, and M4 muscarinic receptor expression in $\mathrm{K} 562$ chronic myelogenous leukemic cells by carbachol. J Recept Signal Transd Res 2011;31:26-32. doi: 10.3109/10799.893.2010.506484

10. Fleisher TA. Apoptosis. Ann Allergy Asthma Immunol 1997;78:245-9. doi: 10.1016/S1081-1206(10)63176-6

11. Ashkenazi A, Dixit VM. Death receptors: Signaling and modulation. Science 1998; 281:1305-8. doi: 10.1126/ science.281.5381.1305

12. Green DR, Reed JC. Mitochondria and apoptosis. Science 1998;281:1309-12. doi: 10.1126/science.281.5381.1309 
13. Hughes D, Mehmet H. Cell proliferation and apoptosis. Advanced Methods. Oxford: Bios Scientific Publishers Limited, 2003.

14. Wyllie AH, Moms RG, Smith AL, Dunlop D. Chromatin cleavage in apoptosis: Association with condensed chromatin morphology and dependence on macromolecular synthesis. J Pathol 1984;142: 67. doi: 10.1002/path.171.142.0112.

15. Wyllie AH, Kerr JFR, Currie AR. Cell death: the significance of apoptosis. Int Rev Cytol 1980;68:251-306.

16. Rosenblum K, Futter M, Jones M, E. Hulme C, Bliss T V $\mathrm{P}$, "ERKI/II regulation by the muscarinic acetylcholine receptors in neurons," J Neurosci 2000;20:977-85. doi: 10.1523/JNEUROSCI.20-03-00977.2000

17. Yu H, Xia H, Tang Q, et al. Acetylcholine acts through $\mathrm{M}_{3}$ muscarinic receptor to activate the EGFR signaling and promotes gastric cancer cell proliferation. Sci Rep 2017;7:40802. doi: 10.1038/srep40802

18. Lowry OH, Rosebrough NJ, Farr AL, Randall RJ. Protein measurement with the Folin phenol reagent. J Biol Chem 1951;193:265-75.

19. Aydın B, Kan B, Cabadak H. The role of intracellular pathways in the proliferation of human K562 cells that is mediated by muscarinic receptors. Leukemia Res 2013;37: 1144-9. doi: 10.1016/j.leukres.2013.05.018

20. Schuller HM. Cell type specific, receptor-mediated modulation of growth kinetics in human lung cancer cell lines by nicotine and tobacco-related nitrosamines. Biochem Pharmacol 1989;38:3439-42. doi: 10.1016/00062952(89)90112-3

21. Maneckjee R, Minna JD. Opioid and nicotine receptors affect growth regulation of human lung cancer cell lines. Proc Natl Acad Sci USA 1990;87:3294-8. doi: 10.1073/pnas.87.9.3294.

22. Cheng K, Zimniak P, Raufman JP. Transactivation of the epidermal growth factor receptor mediates cholinergic agonist-induced proliferation of H508 human colon cancer cells. Cancer Res 2003;63:6744-50.

23. Shant J, Cheng K, Marasa BS, Wang JY, Raufman JP. Aktdependent NF-kappaB activation is required for bile acids to rescue colon cancer cells from stress-induced apoptosis. Exp Cell Res 2009;315:432-50. doi: 10.1016/j.yexcr.2008.11.003

24. Peng Z, Heath J, Drachenberg C, Raufman JP, Xie G. Cholinergic muscarinic receptor activation augments murine intestinal epithelial cell proliferation and tumorigenesis. BMC Cancer 2013;13:204. doi: 10.1186/1471-2407-13-204

25. Raufman JP, Shant J, Xie G, et al. Muscarinic receptor subtype-3 gene ablation and scopolamine butylbromide treatment attenuate small intestinal neoplasia in Apcmin/+ mice. Carcinogenesis 2011;32:1396-402. doi: 10.1093/ carcin/bgr118

26. Raufman JP, Samimi R, Shah N,et al. Genetic ablation of M3 muscarinic receptors attenuates murine colon epithelial cell proliferation and neoplasia. Cancer Res 2008;68:3573-8. doi: 10.1158/0008-5472.CAN-07-6810

27. Cheng K, Shang AC, Drachenberg CB, Zhan M, Raufman J P. Differential expression of $\mathrm{M}_{3}$ muscarinic receptors in progressive colon neoplasia and metastasis. Oncotarget 2017;8: 21106-14. doi: 10.18632/oncotarget.15500

28. Cabadak H, Kücükibrahimoğlu E, Aydin B, Kan B, Gören MZ. Muscarinic receptor- mediated nitric oxide release in a K562 erythroleukaemia cell line. Auton Autacoid Pharmacol 2009;29:109-15. doi: 10.1111/j.1474-8673.2009.00431.x

29. Cabadak H, Aydin B, Kan B. Muscarinic receptor mediated cAMP response in human K562 chronic myelogenous leukemia cells. Turk J Biochem 2011;36:18-92.

30. Kodaira M, Kajimura M, Takeuchi K, Lin S, Hanai H, Kaneko E. Functional muscarinic $\mathrm{m} 3$ receptor expressed in gastric cancer cells stimulates tyrosine phosphorylation and MAP kinase. J Gastroenterol 1999;34: 163-71. doi: 10.1007/ s005.350.050238

31. Fujii T, Tsuchiya T, Yamada S, et al. Localization and synthesis of acetylcholine in human leukemic T cell lines. J Neurosci Res 1996;44:66-72. doi: 10.1002/(SICI)10974547(19960401)44:1\&1t;66::AID-JNR9\&gt;3.0.CO;2-G

32. Kawashima K, Fujii T. Extraneuronal cholinergic system in lymphocytes. Pharmacol Ther 2000;86:29-48. doi: 10.1016/ S0163-7258(99)00071-6.

33. Shah N, Khurana S, Cheng K, Raufman JP. Muscarinic receptors and ligands in cancer. Am J Physiol Cell Physiol 2009;296:C221-32. doi: 10.1152/ajpcell.00514.2008

34. Guizetti M, Moore NH, Van DeMark KL, Giordano G, Costa LG. Muscarinic receptor-activated signal transduction pathways involved in the neuritogenic effect of astrocytes in hippocampal neurons. Eur J Pharmacol 2011;659:102-7. doi: 10.1016/j.ejphar.2011.03.019 